\title{
Migrant Informal Workers: A Study of Delhi and Satellite Towns
}

\author{
Ram Singh Bora \\ Institute of Economic Growth, Delhi, India \\ Email: rsbora@iegindia.org
}

Received 14 December 2013; revised 20 January 2014; accepted 20 February 2014

Copyright (C) 2014 by author and Scientific Research Publishing Inc.

This work is licensed under the Creative Commons Attribution International License (CC BY). http://creativecommons.org/licenses/by/4.0/

(c) (i) Open Access

\begin{abstract}
In India, the activities of the secondary and tertiary sectors are concentrated mostly in large towns and cities, and attract internal migration. Workers' participation has led to spectacular growth in the economy during the past two decades. By analysing data collected from slum households in three states, i.e. the National Capital Territory (NCT) of Delhi, and in two towns of the National Capital Region (NCR) of Haryana and Uttar Pradesh states in India, this paper seeks to assess if this growth has improved workers' employment conditions. The finding reveals that the workers are employed in low-productivity jobs with low incomes and wages; they work without job safety, medical health and social security provisions. All these deteriorate both living and working conditions of the workers. In spite of their working and living in one of the most developed parts of the country they live economically marginalized and neglected life.
\end{abstract}

\section{Keywords}

Rural-Urban Migration, Destinations, Informal Worker, Slum Dwellers, Migrant Workers, Socially Disadvantaged Groups, Below Poverty Line and above Poverty Line Income Groups

\section{Introduction}

In the developing countries, the secondary and tertiary sector's activities are concentrated mainly in large and medium towns. This process of economic development has attracted internal migration in developing countries - at least two-thirds of adults in many large and expanding cities of developing counties are in-migrants. In India, it is evident that the states with higher per capita income and larger non-agricultural sector show not only high in-migration, but also high rate of out-migration (Bhagat, [1]; Bora, [2]). On the other side it is also evident that the states which have less developed status of their economy, sending more out-migrants than they are receiving, virtually, are net loser of their population. Such trends suggest that the push factors have been far more 
effective in inducing a large volume of mobility (Rao, [3]; de Haan and Rogaly, [4]; Mitra, [5]). This shift of population from less developed states has been followed by a corresponding increase in the proportion of the urban population, and subsequently, an increase in the proportion of the unorganized workforce.

With the introduction of policies of reforms and globalization, the impact of these measures is highly visible mainly in larger towns and cities in the form of infrastructural development, industrial expansion, commercial diversification, communication, transport and even in social development activities. All these have attracted migrants to urban areas; as most jobs for new migrants are available in the informal sector of economy, thus marking a progression in the sector. Over time the pattern of participation of workers in the economy has changed particularly in the primary sector involvement of workers has reduced from 66.0 percent in 1983-1984 to 53.2 percent in 2009-2010 (RBI, [6]). The decline of participation in the primary sector has accompanied with the rise of secondary and tertiary sector employment. The expectations of job availability in secondary and tertiary activities have led the migration of rural workers towards towns and cities. With this trend the level of urbanization in the country has increased from 27.7 in 2001 to 31.1 percent in 2011, an increase of 3.3 percent point over 2001 census (Census, [7]; Census, [8]). The 2011 census on urbanization as well as a study on the components of urban growth reveals that the contribution of net rural-urban classification and rural to urban migration has increased from 42.0 percent in 1991-2001 to 56.0 percent in 2001-2012 (Bhagat, [9]; Kundu, [10]). Although separate data for each component are not yet available, the rising trend of a large number of new towns in 2011 does show an increment in mobility as a component of urban growth (Census, [8]). Certainly, all these caused an increase in the proportion of the unorganized workforce and an increase of informal activities.

In the informal activities, workers do not have employment or work security or social security and remain poor and vulnerable throughout their working and social life. The formal sector job opportunities for the unskilled and less educated workers continue to shrink, and the employment created during the period of economic reform remains entirely informal. At the national level, the unorganized sector constitutes 93 percent of the workforce (NSSO, [11]; NSSO, [12]). This shows the significance of this sector for the rural migrant workers. Similarly, the importance of informal workers can be further explained as this sector's contribution in the GDP income is higher (55.0 percent) than the organized sector ( 45.0 percent) ${ }^{1}$. This indicates the extent to which the informal sector dominates the Indian economy.

Over the past two decades, the economy has experienced a reasonably high growth rate. The high GDP growths since 1990s have not been possible without migration of workers. Rising GDP is expected to improve workers' productivity, increase their income faster and subsequently improve workers' working and living conditions. In this context, the present study attempts to examine whether the migrant workers living in slums have benefited from the spectacular economic growth in their surroundings. Certainly, an improvement in their conditions will be a realization of the dream of inclusive growth. Accordingly, this paper starts with an introductory section; it then briefly discusses about the methodology and examines the socio-economic profile of the migrant sample households and their living conditions in the slums in Section 2. Section 3 discusses the salient characteristics of the migrant workers, and the conditions of work for the migrant workers are examined in Section 4. Finally Section 5 summarizes the main findings of the study and provides some suggestions.

\section{Methodology and the Profile of the Migrant Households and Living Conditions in Slums}

Methodology: To discuss above mentioned issues the data has been drawn from the Indian Council of Social Science Research (ICCSR) sponsored research project. The data are related to the 716 migrant's slum households, located in three states namely the National Capital Territory (NCT) of Delhi, and two towns of the National Capital Region (NCR) i.e. Panipat town of District Panipat in Haryana and Pilkhuwa town of Ghaziabad District in Uttar Pradesh. The National Capital Region (NCR) includes both the latter locations, and in all these locations informal activities dominates increasingly. Thus the findings of the study are based on the analysis of the survey of 416 households from the NCT of Delhi and 150 each from Panipat town of Haryana State and Pilkhuwa town of Uttar Pradesh state, both falls in the NCR Region, in all 716 households are included. The migrant workers working in the informal activities are approached only in these households and not at their workplace. Pilkhuwa and Panipat are famous for their textile products, with the influx of migrant's population, the status of essential facilities and services in all these localities particularly infrastructural facilities were found

${ }^{1}$ National Account Statistics, CSO, Government of India, 2009-2010, issue. 
in doldrums. In the NCT of Delhi, while visiting to slum localities, the gloomy face of glittering was quite visible. The NCR localities are far better than the NCT of Delhi when it comes to essential services.

\subsection{Sample Households Profile}

The sample formation leads us to a comparative study of the NCT and the NCR region. This section presents a brief description of the profile of sample households and socio-economic characteristics of the slum dwellers in their destinations such description is an indicative of the residents' status of wellbeing, poverty, education, health status and quality of their work.

In each location among the household's head, most of them are workers too. In the above sample female respondents are few in number; their proportion was higher in Delhi (9.4 percent) than in Haryana (6 percent) and UP (4 percent). Table 1 and Table 2 present the sex of the respondents and size of the households, taking all households together, the mean household size was estimated at 5.1 persons_-far higher than the national average of 4.7 persons per family (NFHS, [13]). In all three states, family size was higher than the national level. The bigger family size among the slum dwellers has a direct relation with their poverty.

On taking the entire sample together, the share of the non-working population worked out to be 39 percent, this proportion is higher than the all-India average of 37 percent (population projection ${ }^{2}$ ). While looking into the dependency burden on the working-age population, the dependency ratio is estimated to be 0.64 percent. It means every 10 persons in the 15 - 59 years working age group support above six persons, for Haryana, this ratio is estimated to be highest, i.e., 10 persons support seven non-working persons. However, being in the working age group does not mean a person actually works and earns.

\subsection{Social and Religious Groups ${ }^{3}$}

In India, certain social groups such as the Scheduled Castes (SCs), Scheduled Tribes (STs), Other Backward Castes and Minorities have historically been disadvantaged and vulnerable. Migrant informal workers are largely linked with the groups which are closely associated with poverty, social identity and poor conditions of work. In our sample too the overwhelming majority of migrants are from the scheduled caste and other backward castes, and also economically poor and vulnerable section of population, including Scheduled Tribes (Table 3).

The SC mostly dominated the urban informal sector and workers chose their dwelling in urban slums. They have encountered deprivation of income, education and occupation due to their poor status. As far as religion is concerned, between the Hindus and Muslims, the literature reveals that a higher proportion of the Muslim population preferred to work in the informal activities, whereas a higher proportion of Hindus work in the formal economy (Varshney, [14]). But in our sample a large majority of the respondents are from Hindu community (79.8 percent), followed by Muslims (19.3 percent) the rests are from the Sikh and Christian community.

\begin{tabular}{cccccccccc}
\multicolumn{1}{c|}{ Table 1. State-wise distribution of respondents by sex. } \\
\hline \multicolumn{7}{c}{ Number } & \multicolumn{5}{c}{ Percentage distribution } \\
\hline Sex & Delhi & Haryana & UP & Total & Delhi & Haryana & UP & Total \\
\hline Male & 377 & 141 & 144 & 662 & 90.63 & 94.00 & 96.00 & 92.46 \\
Female & 39 & 9 & 6 & 54 & 9.38 & 6.00 & 4.00 & 7.54 \\
Total & 416 & 150 & 150 & 716 & 100 & 100 & 100 & 100 \\
\hline
\end{tabular}

Note: Except for Table 7, data for all Tables 1-22 and Figure 1 and Figure 2 have been drawn from the author's primary survey conducted for the ICSSR-sponsored project during 2011 to 2012 in the National Capital Region of Delhi, India.

\footnotetext{
${ }^{2}$ Population projection, May 2006, Office of the Registrar General \& Census Commissioner India.

${ }^{3}$ The Scheduled Castes and Scheduled Tribes comprise about 16.6 percent and 8.6 percent, respectively, of India's population (or about 25.2 percent altogether, according to the 2011 census). The NSSO 61st Round (July 2004 to June 2005) report on "Employment and Unemployment Situation among Social Groups in India" gave an estimate of OBCs constituting 41\% of the population. Our Constitution contains various provisions for the development of such marginalized groups, for instance, Article 341 for SCs, Article 342 for STs, Article 340 for OBCs. http://planningcommission.nic.in/plans/planrel/fiveyr/11th/11_v1/11v1_ch6.pdf
} 


\subsection{Asset Distribution}

The human capital formation in terms of education is least among the respondents of our sample; similarly, limited access to physical capital, such as land and housing, among unorganized workers also acts as a major constraint in the acquisition of good jobs and the growth of self-employment activities. At their origin a large majority (500 households) or 70 percent-was landless. Among the respondents in Haryana, the proportion of landlessness is higher (81 percent) than the total sample average presented in Table 4.

Although respondents with 1 - 3 acres of land are not landless, most belong to the marginal or land-poor category. Land is an important asset; it provides a safety net to the workers against job uncertainty in the labour

Table 2. Working and non-working population of the total sample household population.

\begin{tabular}{ccccc}
\hline & Delhi & Haryana & UP & Total \\
\hline Workers $(15-59)$ & 60.9 & 58.4 & 64.7 & 61.1 \\
Children $(0-4)$ & 34.7 & 40.1 & 33.9 & 35.7 \\
Above 60 & 4.4 & 1.5 & 1.4 & 3.2 \\
Total & 100 & 100 & 100 & 100 \\
Non-worker (\%) & 39.1 & 41.6 & 35.3 & 38.9 \\
& Dependency ratio & & & \\
Non-working to working population & 0.64 & 0.71 & 0.55 & 0.64 \\
Family size & 5.1 & 5.2 & 4.8 & 5.1 \\
\hline
\end{tabular}

Table 3. Distribution of respondents by caste.

\begin{tabular}{ccccc}
\hline Caste & Delhi & Haryana & UP & Total \\
\hline SC & 38.7 & 50.7 & 49.3 & 43.4 \\
ST & 0.5 & 0.0 & 26.7 & 5.9 \\
OBC & 33.2 & 40.0 & 24.0 & 32.7 \\
Others & 27.6 & 9.3 & 0.0 & 18.0 \\
Total & 100 & 100 & 100 & 100 \\
\hline
\end{tabular}

Table 4. Asset ownership (percent).

\begin{tabular}{ccccc}
\hline Own land at village & Delhi & Haryana & UP & Total \\
\hline Yes & 31.3 & 19.3 & 38.0 & 30.2 \\
No & 68.8 & 80.7 & 62.0 & 69.8 \\
Total & 100 & 100 & 100 & 100 \\
\hline Acres of holding & Delhi & Haryana & UP & Total \\
\hline Up to 1.0 & 26.2 & 10.3 & 3.5 & 18.1 \\
1.1 - 3.0 & 44.6 & 69.0 & 59.6 & 51.9 \\
3.1 - 5.0 & 17.7 & 20.7 & 24.6 & 19.9 \\
5.1 and above & 11.5 & 0.0 & 12.3 & 10.2 \\
Total & 100 & 100 & 100 & 100 \\
\hline Mean acres of holding & 3.1 & 2.6 & 3.49 & 3.13 \\
\hline
\end{tabular}


market, low wages, untimely payment and uncertainty of job availability. In our sample, a large majority of the migrant respondents are landless. For them, landlessness played an important role in their out-migration. For the landless, vulnerability is more pronounced since they become migrant casual workers in various manual activities. Even in the case of land-owning households, migration of household members deteriorates the productivity of land.

As compared to landlessness (70 percent), only 22 percent of the total respondents did not own a house at their origin; the rest (78 percent) of the respondents owned a house (Table 5). Some said its size was very small and many reported it to be in a dilapidated state.

\subsection{Poverty Status of Migrant Households in Their Destinations}

The total household income is often proxies by total expenditure, and used for measuring the household status. The expenditure data include consumption of food and non-food items. The expert group estimated the poverty line income by considering household expenditure in rural and urban areas nationwide, updating 2004-2005 prices and using the consumer price index (CPI) for industrial workers. Since our sample respondents reside in the urban areas of three states, accordingly we estimated the monthly household income that determined their present poverty status (Table 6).

\section{During the Year 2009-2010, the Average Value of One Dollar Was Rupees 45.12 INR}

For the year 2009-2010, the monthly per capita expenditure that determines the poverty status of households residing in the NCT of Delhi was Rs. 807.48. In NCR towns, the amount was estimated at Rs. 664.64 for Haryana and Rs. 636.67 for UP. The poverty status of the households was easily known by applying these estimates for our sample households' income as well as per capita income. If the sample households' per capita monthly income was lower than the income estimated for a particular location, they were included in the below poverty line (BPL) income category; similarly, if the income was higher, they were placed above the poverty line (APL) income category (Table 7).

Out of the total sample households, a little above 49 percent were BPL income households, with an average monthly household expenditure of Rs. 3329. As the family size of the BPL families was 5.81 persons, the per capita income per month is Rs. 573 and the per capita per day is Rs. 19.1. Table 8, presents the distribution of families by location and shows that the large majority of households (60 percent) are under the poverty line in-

\begin{tabular}{ccccc}
\hline Table 5. Own house at origin. & & & \\
\hline Own house at origin & Delhi & Haryana & UP & Total \\
\hline Yes & 76.0 & 78.0 & 85.33 & 78.35 \\
No & 24.0 & 22.0 & 14.67 & 21.65 \\
Total & 100 & 100 & 100 & 100 \\
\hline
\end{tabular}

Table 6. Income determining present poverty status and estimated per capita expenditure in Rs. (in Indian National Rupees, INR).

\begin{tabular}{cccccccc}
\hline & \multicolumn{7}{c}{ Consumer price index } \\
\hline Inflation rate (\%) & & 4.2 & 4.2 & 5.3 & 6.4 & 8.3 & 10.9 \\
\hline State & Starting & 2005 & 2006 & 2007 & 2008 & 2009 & 2010 \\
Delhi & 612.9 & 638.7 & 665.5 & 700.8 & 745.6 & 807.5 & 895.5 \\
Haryana & 504.5 & 525.7 & 547.8 & 576.8 & 613.7 & 664.6 & 737.1 \\
UP & 483.3 & 503.6 & 524.7 & 552.5 & 587.9 & 636.7 & 706.1 \\
India (urban) & 538.6 & 561.2 & 584.8 & 615.8 & 655.2 & 709.6 & 786.9 \\
\hline
\end{tabular}

Source: https://www.cia.gov/library/publication/the-world-factbook/fields/2092.html, accessed 17 January 2010. 
Table 7. BPL and APL households (\%) and per household expenditure (in Rupees).

\begin{tabular}{|c|c|c|c|c|c|c|c|c|c|}
\hline \multicolumn{5}{|c|}{$\%$ of BPL HHs } & \multicolumn{4}{|c|}{ Monthly expenditure per HH in Rs. } & \multirow[t]{2}{*}{$\begin{array}{c}\text { Per capita } \\
\text { Expenditure in Rs. }\end{array}$} \\
\hline & Delhi & Haryana & UP & Total & Delhi & Haryana & UP & Total & \\
\hline BPL & 59.9 & 30.0 & 39.3 & 49.3 & 3378 & 3743 & 2805 & 3329 & 573 \\
\hline APL & 40.1 & 70.0 & 60.7 & 50.7 & 4985 & 4194 & 3999 & 4509 & 1041 \\
\hline Total & 100 & 100 & 100 & 100 & 4023 & 4059 & 3529 & 3927 & 770 \\
\hline
\end{tabular}

Household's income has been estimated taking into account the prevailing consumer price index in the respective state for the years 2009 and 2010. Source:

https://www.cia.gov/library/publication/the-world-factbook/field/2092html (accessed 17 January 2010).

Table 8. Housing ownership by type of house.

(a)

\begin{tabular}{ccccc}
\hline Ownership & Delhi & Haryana & UP & Total \\
\hline Own house & 93.3 & 60.7 & 49.3 & 77.2 \\
As tenant & 6.7 & 38.7 & 49.3 & 22.3 \\
Others $^{*}$ & 0.0 & 0.7 & 1.3 & 0.4 \\
Total & 100 & 100 & 100 & 100 \\
Average rent & & & & \\
Paid by tenants & 698 & 725 & 590 & 658 \\
\hline
\end{tabular}

(b)

\begin{tabular}{ccccc}
\hline Type of housing & Delhi & Haryana & UP & Total \\
\hline Pucca & 31.3 & 30.0 & 50.0 & 34.9 \\
Semi-pucca & 33.9 & 58.7 & 45.3 & 41.5 \\
Kachha & 34.9 & 11.3 & 4.7 & 23.6 \\
Total & 100 & 100 & 100 & 100 \\
\hline
\end{tabular}

(c)

\begin{tabular}{cccc}
\hline \multicolumn{4}{c}{ Bathing facility } \\
\hline Bathing facility $^{*}$ & Delhi & Haryana & UP \\
\hline Bathroom attached & 4.6 & 34.7 & 30.0 \\
Common bathroom & 12.0 & 17.3 & 16.0 \\
Bathing in open & 62.0 & 14.7 & 21.3 \\
\hline
\end{tabular}

"The above table is related to only "YES" condition of Respondent, some were using work place facilities, friends and neighbors facilities etc.

(d)

\begin{tabular}{|c|c|c|c|c|}
\hline \multicolumn{5}{|c|}{ Source of drinking water toilet facility } \\
\hline Source & Delhi & Haryana & UP & Total \\
\hline Tap connection & 7.0 & 57.3 & 8.7 & 17.9 \\
\hline Common tap & 68.0 & 33.3 & 5.3 & 47.6 \\
\hline Hand pump & 2.9 & 0.7 & 63.3 & 15.1 \\
\hline Common hand pump & 4.1 & 6.0 & 26.7 & 9.2 \\
\hline Tube well & 18.8 & 2.0 & 0.0 & 11.3 \\
\hline Any other ${ }^{*}$ & 3.1 & 0.7 & 0.0 & 2.0 \\
\hline
\end{tabular}

*Some were using multiple sources only yes conditions. 
(e)

\begin{tabular}{ccccc}
\hline Toilet facility & Delhi & Haryana & UP & Total \\
\hline Toilet attached & 14.9 & 66.0 & 63.3 & 35.8 \\
Common toilet & 39.2 & 18.7 & 16.0 & 30.0 \\
Open field & 33.9 & 14.7 & 19.3 & 26.8 \\
Scavenging facility & 0.2 & 0.0 & 0.0 & 0.1 \\
\hline
\end{tabular}

come in the NCT of Delhi. Households estimated as BPL are the lowest in Haryana (30 percent), followed by UP (39 percent).

All these localities belong to a very developed part of their respective state; in terms of socio-economic development, the regions located within NCT and NCR are considered to have advanced the most. Despite significant economic progress, per month per capita expenditure for the entire sample worked out to be just Rs. 770 a trickle-down effect of the growing economy in their surrounding has not taken place. The slum dwellers have failed to become a part of the inclusive growth.

\subsection{Living Conditions of Migrant Informal Workers in Slums}

Due to rural-urban migration, cities grow in size, and slums are created, mainly urban facilities do not grow at the same rate. With the hope of minimising living costs, including rent, migrants choose dwelling sites where either the amenities or services are either poor or unavailable (Bora and Tyagi, [15]). One of the basic indices of living conditions in a city is housing. Although a large proportion (77.2 percent) of the respondents owned the house, the structures are poorly built and crowded housing conditions are considered prone to health hazards leading to a bad quality of life (Table 8). Despite their bad living conditions, these inhabitants preferred urban life because the city provided those jobs and other social amenities, which the villages and small towns did not.

Very few households (16.0 percent) are reported to have an attached bathroom; in this regard Delhi is the worst. About toilets, a large proportion of the households in Delhi defecate in open field or road side (34.0 percent), such practices are far lower in the NCR towns. Drinking water and sanitation facilities are considered an important component of healthy living. Both have important influences on the health of the family members. We found that only 18 percent of the total sample households have tap (piped) water for drinking. Mostly, depend on common tap, hand pumped water and also many other sources. The findings reveal that the clean and reliable sources of drinking water are lacking, further the users are drinking without purifying or filtering the collected water. In most places street light facility was not found. However, overall 84.0 percent of the households are electrified, the supply of electricity is irregular mostly in UP and Delhi.

\subsection{Household Durables}

Land and house comprises major share of the household assets, however, durable goods also play an important role, and goods maintain certain standard of the households. We asked only about few items, as compared to by cycle and motorcycle/scoter, a large majority of the households are in possession of the goods like mobile phones (83.3 percent) and TV sets (71.0 percent) (Table 9). The analysis of this finding reveals that the migrant slum households are poor in assets possession, consumption pattern, possession of households' durables as well as availability of basic amenities, it is easy to say that the standard of living of the migrant slum dwellers is very poor.

Both the NCT and its satellite towns have experienced a reasonably high economic growth rates, and the progress continues. However, the analyses did not reveal that the growth is inclusive. The spectacular growth in these parts of the country has spread total inequality as far as slum dwellers are concerned.

\section{Characteristics of Migrant Workers and Their Working Conditions}

The majority of the migrants mainly originate from the slow growing less developed states, i.e., eastern, central and western part of the Indian states and states with higher inequality in income earnings and assets distribution. Migrants posses certain characteristics and discussed in this section. 


\subsection{Migrants Workers' Age on Arrival}

Migrants reached at their destinations when they were in their teens or just passing through teen ages, for the entire sample an average age on arrival was worked out to be 19.6 years, it was just 19.0 years for males and 22.1 years for females (Table 10). This reveals that the females generally join after marriage or settling down of the male members.

The data analysis in the above table is related to the total of 924 migrant workers, workers born in these households (168 workers) in destinations have not been included while analyzing age at migration. The migrants in the age group of 15 - 24 years are few, This reveals that the recent migrant workers are not being accommodated. This is mainly because of the space problems; any further extension for new construction is not possible due to limited common land in their localities. The present average age for the entire sample worked out to be 39.0 years, it seems that there is no age bar in the informal sector; even workers above 59 years were also working. Among the workers, female share in total workers is less than one-fifth (19.0 percent), the rest is a large majority of males (81.0 percent). The process of work participation is highly selective and is in favour of male workers (Bora and Tyagi, [15]).

The majority of the migrant workers possess very low levels of human capital. Of the total workers, illiteracy is estimated to be very high (45.0 percent), except in UP (34.0 percent), more than half of the workers (51.4 percent) in Haryana are illiterate, and Delhi also have a huge proportion (47.0 percent) of illiterate (Table 11). It is far higher than the national level proportion of illiterate labour force (39.0 percent, NSS survey 2004-2005). Illiteracy among women workers was ranging from 73.0 percent to 83.0 percent. Those who are literate and above, have received an average years of schooling by 6.2 years, our sample workers received education about 4.0 years less than that received by workers in the organized sector (10.1 years). In all the locations, among the workers effective and functioning literacy is lacking ${ }^{4}$. An acquisition of skill is only having with a small number of workers, as the importance of education is well known, it is key for obtain gainful, productive and remunerative employment.

\begin{tabular}{ccccc}
\multicolumn{2}{l}{ Table 9. Durable goods. } & & & \\
\hline Asset ownership & Delhi & Haryana & UP & Total \\
\hline Car & 0 & 0 & 0 & 0 \\
Two wheeler & 2.9 & 1.3 & 2.0 & 2.4 \\
Bicycle & 25.0 & 45.3 & 53.3 & 35.2 \\
Telephone & 0.7 & 3.3 & 0.0 & 1.1 \\
Mobile & 78.4 & 93.3 & 83.3 & 82.5 \\
Television & 70.4 & 81.3 & 60.0 & 70.5 \\
Radio & 9.1 & 5.3 & 6.7 & 7.8 \\
Music system & 1.7 & 0.7 & 0.7 & 1.3 \\
Refrigerator & 24.3 & 11.3 & 17.3 & 20.1 \\
Cooler/ACs & 24.8 & 17.3 & 10.7 & 20.3 \\
\hline
\end{tabular}

\begin{tabular}{ccccc}
\multicolumn{5}{c}{ Table 10. Average age on arrival (years). } \\
\hline Sex & Delhi & Haryana & UP & Total \\
\hline Male & 18.5 & 18.7 & 20.6 & 19.0 \\
Female & 22.2 & 21.4 & 22.7 & 22.1 \\
Total & 19 & 19.4 & 21.0 & 19.6 \\
\hline
\end{tabular}

\footnotetext{
${ }^{4}$ As Ray (1998) puts it, to invest in human capital, a person needs to distance himself from the labour market for some time and devote resources on him. However, for these poor people, the opportunity cost of doing so is so large, that despite the availability of cheap (and often free) education, they do not avail it.
} 
Before migration, a very small proportion of males and females had some skills (Table 12). Gender differentials in acquired skills were noticed.

\subsection{Occupation of Migrant Workers}

At the time of migration, only 3.2 percent of males were salaried workers but at their destination, at the time of survey about 43.0 percent were working as salaried workers.

Before migration, not a single woman was salaried worker; however, at the time of survey, little over 49.0 percent women were working as salaried workers. Some women are also working as a casual worker. A comparative picture shows that over time, a great change in occupation and employment pattern has taken place after migration (Table 13).

\subsection{Present Skilled Occupations: Skill Acquisition Process}

After migrating to the city, the majority had picked up required skills for the job of a labourer and mason. As seen, above one-quarter of the total surveyed are trained for such a work only, and this figure is especially high in Delhi (over 30 percent), followed by Haryana (21.0 percent) and UP (only 19.0 percent). For labour in UP, the skills are more or less evenly divided between occupations such as craft and trades (20.0 percent), plant and machine operator (20.0 percent), handloom operator (18.0 percent) and other elementary occupations (14.0 percent). Delhi has a great divergence from the other two states (see appendix for present occupation). It has the least number of trained handloom operators ( 0.6 percent) and plant and machinery operators (4.4 percent) while this figure is high for both Haryana (19.8 percent) and UP (19.9 percent). Similarly, Delhi has the highest influx

\begin{tabular}{|c|c|c|c|c|c|c|c|c|c|c|c|c|}
\hline \multicolumn{13}{|c|}{ Percentage distribution of workers by literacy } \\
\hline \multicolumn{4}{|l|}{ Delhi } & \multicolumn{3}{|c|}{ Haryana } & \multicolumn{3}{|c|}{ UP } & \multicolumn{3}{|c|}{ Total } \\
\hline & M & $\mathrm{F}$ & $\mathrm{T}$ & M & $\mathrm{F}$ & $\mathrm{T}$ & M & $\mathrm{F}$ & $\mathrm{T}$ & M & $\mathrm{F}$ & $\mathrm{T}$ \\
\hline Literate & 1.9 & 2.7 & 2.0 & 0 & 0 & 0 & 1.8 & 4.4 & 2.4 & 1.5 & 2.3 & 1.6 \\
\hline Illiterate & 40.8 & 80.0 & 46.7 & 40.5 & 83.3 & 51.4 & 23.5 & 73.3 & 34.1 & 36.9 & 79.3 & 44.9 \\
\hline Below primary & 16.7 & 6.7 & 15.2 & 15.8 & 7.4 & 13.7 & 13.3 & 2.2 & 10.9 & 15.7 & 5.7 & 13.9 \\
\hline Primary & 13.8 & 5.3 & 12.6 & 12.7 & 5.6 & 10.8 & 13.3 & 6.7 & 11.8 & 13.5 & 5.7 & 12.0 \\
\hline Middle & 17.4 & 1.3 & 15.0 & 19.6 & 1.9 & 15.1 & 30.1 & 13.3 & 26.5 & 20.7 & 4.6 & 17.6 \\
\hline Matric & 6.8 & 4.0 & 6.4 & 8.9 & 1.9 & 7.1 & 12 & 0 & 9.5 & 8.4 & 2.3 & 7.3 \\
\hline Inter & 2.1 & 0 & 1.8 & 1.9 & 0 & 1.4 & 4.8 & 0 & 3.8 & 2.7 & 0 & 2.2 \\
\hline Graduate & 0.2 & 0 & 0.2 & 0.6 & 0 & 0.5 & 1.2 & 0 & 0.9 & 0.5 & 0 & 0.4 \\
\hline Technical & 0.2 & 0 & 0.2 & 0 & 0 & 0 & 0 & 0 & 0 & 0.1 & 0 & 0.1 \\
\hline Total & 100 & 100 & 100 & 100 & 100 & 100 & 100 & 100 & 100 & 100 & 100 & 100 \\
\hline Average years of schooling ${ }^{*}$ & 6.1 & 5.0 & 6.0 & 6.5 & 5.0 & 6.4 & 7.1 & 5.7 & 7.0 & 6.5 & 5.2 & 6.2 \\
\hline
\end{tabular}

Table 12. Acquisition of skill on arrival (\%).

\begin{tabular}{cccccccccccccccc}
\hline & \multicolumn{3}{c}{ Delhi } & \multicolumn{3}{c}{ Haryana } & \multicolumn{3}{c}{ UP } & \multicolumn{3}{c}{ Total } \\
\hline & M & F & T & M & F & T & M & F & T & M & F & T \\
\hline Acquired & 9.6 & 2.7 & 8.6 & 5.7 & 1.9 & 4.7 & 12.0 & 2.2 & 10.0 & 9.3 & 2.3 & 8.0 \\
Not acquired & 90.4 & 97.3 & 91.4 & 94.3 & 98.1 & 95.3 & 88.0 & 97.8 & 90.0 & 90.7 & 97.7 & 92.0 \\
Total & 100 & 100 & 100 & 100 & 100 & 100 & 100 & 100 & 100 & 100 & 100 & 100 \\
\hline
\end{tabular}


Table 13. Present and past occupations.

\begin{tabular}{|c|c|c|c|c|c|c|c|c|c|c|c|c|}
\hline & \multicolumn{2}{|c|}{ Delhi } & \multicolumn{2}{|c|}{ Haryana } & \multicolumn{2}{|c|}{ Uttar Pradesh } & \multicolumn{3}{|c|}{$\begin{array}{l}\text { At the time } \\
\text { of migration }\end{array}$} & \multicolumn{3}{|c|}{$\begin{array}{l}\text { At the time } \\
\text { of survey }\end{array}$} \\
\hline & $\begin{array}{l}\text { At the time } \\
\text { of migration }\end{array}$ & $\begin{array}{l}\text { At the time } \\
\text { of survey }\end{array}$ & $\begin{array}{l}\text { At the time of } \\
\text { migration }\end{array}$ & $\begin{array}{l}\text { At the time } \\
\text { of survey }\end{array}$ & $\begin{array}{l}\text { At the time of } \\
\text { migration }\end{array}$ & $\begin{array}{l}\text { At the time } \\
\text { of survey }\end{array}$ & M & $\mathrm{F}$ & $\mathrm{T}$ & M & $\mathrm{F}$ & $\mathrm{T}$ \\
\hline Salaried & 1.40 & 44.71 & 2.36 & 42.92 & 8.53 & 39.34 & 4.0 & 0.0 & 3.2 & 41.6 & 49.4 & 43.1 \\
\hline $\begin{array}{l}\text { Casual/wage } \\
\text { labourer }\end{array}$ & 25.95 & 34.53 & 30.66 & 45.75 & 26.54 & 45.49 & 30.3 & 13.8 & 27.2 & 40.7 & 35.1 & 39.6 \\
\hline Own account & 10.38 & 20.75 & 6.13 & 11.32 & 11.37 & 15.16 & 11.5 & 1.7 & 9.6 & 17.7 & 15.5 & 17.3 \\
\hline Unemployed & 33.33 & 0 & 28.77 & 0 & 25.12 & 0 & 28.0 & 40.8 & 30.4 & 0 & 0 & 0 \\
\hline Student & 17.17 & 0 & 14.15 & 0 & 8.06 & 0 & 17.2 & 2.3 & 14.4 & 0 & 0 & 0 \\
\hline Others & 8.18 & 0 & 13.68 & 0 & 20.38 & 0 & 6.0 & 39.1 & 12.2 & 0 & 0 & 0 \\
\hline $\mathrm{NA}^{*}$ & 3.59 & 0 & 4.25 & 0 & 0 & 0 & 3.1 & 2.3 & 2.9 & 0 & 0 & 0 \\
\hline Total & 100 & 100 & 100 & 100 & 100 & 100 & 100 & 100 & 100 & 100 & 100 & 100 \\
\hline
\end{tabular}

*Note: NA implies children (0 - 14 years) who are neither student nor employed.

of service workers for shop and marketing works; more than 10 percent of migrants here do this, while the corresponding figure for both Haryana and Uttar Pradesh is less than half of it (Figure 1).

\subsection{Reasons for Migration: Internal Migration}

Some of the factors determining out-migration which have been discussed in the previous sections are the impelling reasons, along apart from factors like perceptions, experiences and expectations of these migrants (Oberai and Singh, [16]). Similarly, in the preceding sections, the discussion on the characteristics of the sample migrants and of the household at their origin and destinations brought to light what could be the possible causes of out-migration for our sample. The results provide strong empirical support to the importance of economic necessity as a factor in the decision to migrate. Among the economic causes, landlessness, unemployment, lack of jobs, poverty, low income and the shortage of land are identified. From the total, around 30.0 percent migrated out for economic reasons; these factors altogether are playing the role of push factors. Push factors are more effective in the case of men as unemployment and non-availability of work have been the main causes of male migration. Among women, household's poverty has been causing females to migrate; in all the states, the proportion of women responses is higher than men. Among the pull factors for their relocation, "better economic prospects" (23 percent) has been the main cause for migration. The improvement factor and income differentials are seen to be relatively more effective in the case of men; it has been mentioned as a better economic prospect. The promotion of schooling in rural areas has stimulated out-migration by the more selective rural youth. Almost 21.0 percent of the workers responded that they migrated in search of better education and skill development. Although landlessness is very high among the workers, but "no land" ( 0.3 percent), "shortage of land" ( 0.9 percent) and poverty ( 7.0 percent), jointly known as the push factors, have not been significant reasons while discussing individually. A few studies have also supported the hypothesis that migrants are attracted to cities in search of better jobs, education and skill development, inducement and entertainment-jointly known as pull factors of migration and also called "bright city lights" impact (Findley, [17]; Oberai and Singh, [16]). Educational opportunities, medical services, entertainment and other facilities are just not there in villages or are available at a modest scale. Additionally, a sizable 13.0 percent of the migrants reported social reasons as their primary reason for migrating across all three states. Although women workers are less in numbers as compared to men, the overwhelming majority of women migrated due to social reasons (Figure 2). Therefore, in the case of females, pull and personal factors are more important. Figure 2 summarises these reasons. In general, the push factors have overriding importance for all sample areas, however, the importance of pull factors shows that their relative influence is greater when income earning and employment opportunities are concerned. Since many workers in our sample are also from urban origin, probably they might know better about income differentials which create the urge to seek out better income and employment. 


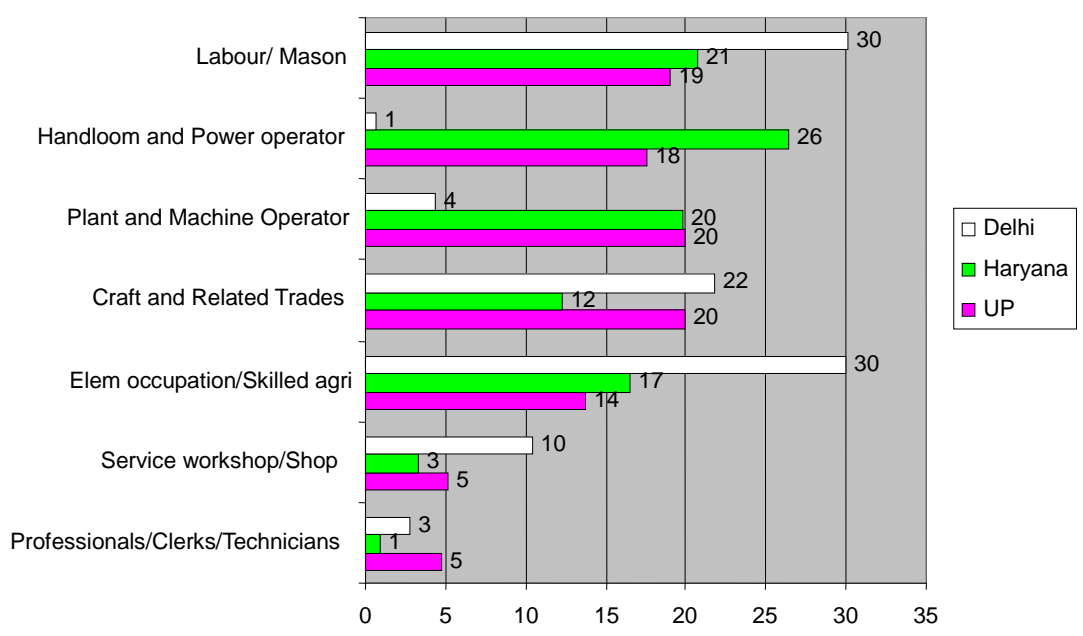

Figure 1. Present occupations of the migrants (\%).

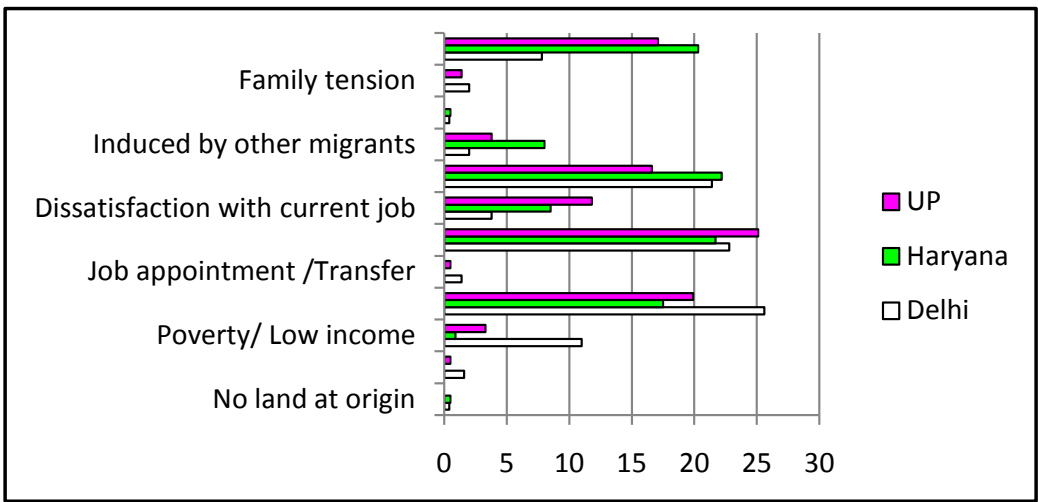

Figure 2. Reasons for migration (\%).

\section{Work Conditions and Environment of Migrant Workers}

The workers those drawing salary and wages, form a total of 912 workers and those working as an own account workers are 168 workers. All these workers are living in 716 migrant respondent households as discussed in the earlier sections.

\subsection{Conditions of Work for Wage and Salaried Workers}

The conditions of work, focuses on the nature of employment; working hours; the average daily earnings, the overtime earnings, if any; and the mode of payment. The physical conditions at work place as well provision of protective instrument along with the overall working environment have also been studied. Among the employed workers, 502 workers are working in NCT of Delhi, and 218 and 192 workers are working at Panipat and Pilkhuwa of NCR respectively. About their job characteristics the actual situations are as follows.

\subsection{Nature of Employment}

If all the sample workers are taken together, nearly half of the workers are employed in temporary jobs, the highest of 51.0 percent in Delhi, followed by 49.5 percent in Haryana, while the lowest of 46.4 percent in Uttar Pradesh (Table 14). The migrants who are lucky enough to enjoy permanent jobs formed around 15.0 percent; the highest of about 17.0 percent in Delhi, and the lowest, 7.8 percent in UP. The casual work activities form quite a significant proportion of around 43.0 percent in Haryana, followed by 38.0 percent in UP and 32.0 percent in Delhi. 


\subsection{Occupation of Workers}

Higher proportion of the workers are engaged in such activities that needed low level of skills, as a result, almost 32.0 percent of the workers are engaged in such occupations like masons, construction workers, laundry workers, maids, watchmen, security guards, gardener and rickshaw pullers. Both male and female are engaged, females are at lower proportion in all the locations. The substantial percentage of about 19 percent are engaged in crafts and related trades, which include motor mechanics and other mechanics, carpenters, electricians, painters, welders, tailors, plumbers, TV mechanics and such other skilled workers. Because of handloom and power loom activities in Haryana and UP, its related plant and machinery operations are higher among male and female in these locations (Table 15).

\subsection{Nature of Organization}

Except manufacturing, the NCT of Delhi is providing varieties of job opportunities as it has plenty of edge over other places, mainly creating more jobs in activities like household services, trade activities, constructions, public administration/defense, also other activities like schools, hospitals, NGOs, food joints, etc. (Table 16).

About the nature of organizations in which the workers are employed, about 23.0 percent could not give any response; in Delhi, the non-response was as high as about 30.0 percent. A little above 38.0 percent of the workers were engaged in manufacturing sector; this percentage was high in both the NCR towns.

\subsection{Registration Status of Their Organization}

About the legal status of their organizations the workers are not aware, often these are factories, workshops, reappear shops and shops. Even than they replied in favour of registration, and nearly 58.0 percent are reported to be registered, under which provision i.e., Factory Act or any other provisions, workers did not know much.

\subsection{Hours of Work}

The average hours of work put by the workers per day are highest in Haryana (9.3 hours per day), followed by

Table 14. Nature of employment.

\begin{tabular}{ccccc}
\hline & Delhi & Haryana & UP & Total \\
\hline Casual & 32.07 & 42.66 & 37.50 & 35.75 \\
Permanent & 16.93 & 7.80 & 15.63 & 14.47 \\
Seasonal & 0 & 0 & 0.52 & 0.11 \\
Temporary & 51.00 & 49.54 & 46.35 & 49.67 \\
Total & 100 & 100 & 100 & 100.00
\end{tabular}

Table 15. Occupation of workers (\%).

\begin{tabular}{|c|c|c|c|c|c|c|c|c|c|c|c|c|}
\hline \multirow{2}{*}{ Occupation } & \multicolumn{3}{|c|}{ Delhi } & \multicolumn{3}{|c|}{ Haryana } & \multicolumn{3}{|c|}{ UP } & \multicolumn{3}{|c|}{ Total } \\
\hline & M & $\mathrm{F}$ & $\mathrm{T}$ & M & $\mathrm{F}$ & $\mathrm{T}$ & M & $\mathrm{F}$ & $\mathrm{T}$ & M & $\mathrm{F}$ & $\mathrm{T}$ \\
\hline Masons \& low skill occupation & 40.9 & 20.3 & 38 & 28.9 & 5.1 & 22.5 & 29 & 8.1 & 25 & 35.9 & 12.1 & 31.6 \\
\hline Craft and related trades & 25.9 & 5.8 & 23.1 & 13.8 & 3.4 & 11 & 16.1 & 16.2 & 16.1 & 21.3 & 7.3 & 18.8 \\
\hline Less skilled occupations including agriculture & 16.2 & 58 & 21.9 & 4.4 & 22 & 9.2 & 4.5 & 13.5 & 6.3 & 11.2 & 35.2 & 15.6 \\
\hline Plant and machine operators, helper & 5.8 & 1.4 & 5.2 & 32.7 & 8.5 & 26.1 & 20.6 & 29.7 & 22.4 & 14.6 & 10.3 & 13.8 \\
\hline Handloom and power loom workers & 0.2 & 2.9 & 0.6 & 17.6 & 61 & 29.4 & 15.5 & 32.4 & 18.8 & 7.1 & 30.3 & 11.3 \\
\hline Service workers, shopkeeper etc. & 7.6 & 11.6 & 8.2 & 1.9 & 0 & 1.4 & 9 & 0 & 7.3 & 6.7 & 4.8 & 6.4 \\
\hline Professionals/technicians/clerks & 3.5 & 0 & 3 & 0.6 & 0 & 0.5 & 5.2 & 0 & 4.2 & 3.2 & 0 & 2.6 \\
\hline Total & 100 & 100 & 100 & 100 & 100 & 100 & 100 & 100 & 100 & 100 & 100 & 100 \\
\hline
\end{tabular}


Table 16. Nature of organizations in which the workers were employed (\%).

\begin{tabular}{ccccccccccccccc}
\hline Name of Organization & \multicolumn{3}{c}{ Delhi } & \multicolumn{3}{c}{ Haryana } & \multicolumn{3}{c}{ UP } & \multicolumn{3}{c}{ Total } \\
\hline & Male & Fem & Total & Male & Fem & Total & Male & Fem & Total & Male & Fem & Total \\
\hline Manufacturing & 15.9 & 11.6 & 15.3 & 70.4 & 76.3 & 72.0 & 54.8 & 83.8 & 60.4 & 35.6 & 50.9 & 38.4 \\
Household as employers & 7.4 & 44.9 & 12.5 & 0.6 & 20.3 & 6.0 & 3.2 & 10.8 & 4.7 & 5.1 & 28.5 & 9.3 \\
Construction & 8.1 & 2.9 & 7.4 & 6.9 & 0 & 5.0 & 12 & 0 & 9.9 & 8.7 & 1.21 & 7.35 \\
Public administration/defense & 8.8 & 2.9 & 8 & 0 & 0 & 0 & 2.6 & 0 & 2.1 & 5.6 & 1.2 & 4.8 \\
Transport/storage/communication & 7.6 & 0 & 6.6 & 0.63 & 0 & 0.5 & 3.2 & 0 & 2.6 & 5.2 & 0.0 & 4.3 \\
Trade & 7.9 & 10.1 & 8.2 & 0 & 0 & 0 & 6.5 & 0 & 5.2 & 5.9 & 4.2 & 5.6 \\
Others & 11.8 & 13 & 12 & 2.52 & 0 & 1.8 & 3.9 & 0 & 3.1 & 8.2 & 5.5 & 7.7 \\
No response & 32.6 & 14.5 & 30.1 & 18.9 & 3.4 & 14.7 & 14 & 5.4 & 12.0 & 25.7 & 8.5 & 22.6 \\
Total & 100 & 100 & 100 & 100 & 100 & 100 & 100 & 100 & 100 & 100 & 100 & 100 \\
\hline
\end{tabular}

UP (8.2 hours) and Delhi (7.6 hours), for Delhi these hours are lower than the standard hours also lower than the total sample average of 8.2 hours. In the NCT of Delhi, many of them are working in such occupations where full day work is not available. The hours put in by the surveyed migrants in the urban sector are varying a lot (NCEUS, [18]). While considering entire sample together, mostly workers are receiving either monthly or daily payments. Monthly contracts are usually enforced for workers in registered firms, while daily wages are given to masons and labourers.

\subsection{Payment of Minimum Wages}

For the informal workers, there is yet no legal backing for the payment they are receiving, and most of them get wages that are lower than the minimum wages prescribed for the unskilled/skilled workers. However, about 11 percent reported that they managed to earn even more than the minimum wages; most of them were skilled and more educated. Therefore, it is true that the investment in skill fetches a good return, as skilled workers earn more than the minimum wages. Overall, if all the sample workers are taken together, between 77.0 to 91.0 percent of the workers were not receiving the minimum wages. This may have connection with the number of hours put in by the workers per day. The higher level of educational attainments is also making its impact, as the average years of schooling is higher in UP. A comparative picture of the minimum wages is given in Table 17.

Our enquiry also reveal that the workers getting less than minimum wages, about a quarter, in-migrated 11 20 years back, and close to 35.0 percent of the workers in-migrated between 20 - 30 years back. Hence, there has been no major improvement in their wages, despite their long stay; they do not enjoy the government stipulated minimum return to their labour. Part time facility for earning was not available; very few were engaged over time work and not found remunerative.

\subsection{Facilities Available at Workplace}

Numerous studies have pointed about the poor working conditions in the unorganised sector in India (Banarjee and Nihila, [19]; Nihila, [20]; NCEUS, [21]). Conditions of work and working environment are known as the availability of facilities like proper work space (includes space and height), ventilation, proper light, illumination, temperature, humidity, hygiene, cleanliness and availability of proper implements to work with. We also analyzed some of the parameters available to them like available facilities at workplace, health parameters and excesses at workplace, i.e., drinking water facility, toilets for men and women, washing facilities, ventilation and height of the working space or rooms (Table 18).

The table reported that the facilities wise standard norms in removing the prevalence of unhygienic and health hazardous conditions were not met. 
Table 17. Payment of minimum wages.

\begin{tabular}{ccccc}
\hline Receipt of wages & Delhi & Haryana & UP & Total \\
\hline Less than minimum wage & 90.84 & 87.61 & 76.56 & 87.06 \\
Equal to minimum wage & 1.59 & 3.21 & 2.08 & 2.08 \\
More than minimum wag & 7.57 & 9.17 & 21.35 & 10.86 \\
Total & 100 & 100 & 100 & 100 \\
\hline
\end{tabular}

\begin{tabular}{|ccccc}
\hline Table 18. Workplace facilities. & \multicolumn{5}{c}{ Percentages } \\
\hline Facilities available at workplace & \multicolumn{4}{c}{ Total } \\
\cline { 2 - 5 } & Delhi & Haryana & UP & To. \\
\hline Drinking water & 99.80 & 100.00 & 99.48 & 99.78 \\
Hand and feet washing facilities & 16.73 & 23.85 & 29.17 & 21.05 \\
Toilet for men & 59.56 & 70.18 & 66.15 & 63.49 \\
Toilet for women & 23.11 & 48.62 & 33.33 & 31.36 \\
Height of roof good enough & 32.27 & 61.47 & 51.04 & 43.20 \\
Ventilation is good & 28.69 & 48.62 & 46.35 & 37.17 \\
\hline
\end{tabular}

\subsection{Activities of Self-Employed Workers}

About 31.0 percent of total workers across the three states reported to be vendors of fruits and non-fruits and operate on the streets, this followed by having own shop/tea shop (26.0 percent). Across the states variation exists in activities like waste collector (Kabadiwala), working as piece rate basis, working as entrepreneur and also working as home based producer with hired labour. The proportion varies in the range of 8.0 to 12.0 percent, in case of Kabadiwala, piece rate work 7.0 percent in Delhi to 29.0 percent in UP and in case of working as entrepreneur with hired labour varies from zero in Delhi to 4.2 percent in Haryana.

\subsection{Location and Nature of Their Activities}

As far as locations and manpower is concerned, very few activities on rental premises (4.2 percent), on an average 18.0 percent operate from their house itself, but this figure touches as high as 45.0 percent in UP. Further owing place out-side is reported highest in Delhi (18.0 percent). Operating from streets or footpath is very common across the states (50.0 percent). About the involvement of man power almost 95.0 worked alone, with the state 100.0 percent touching in Haryana. Less than two percent employed more than two workers. This gives us a very clear picture of the scale and nature of the enterprises run by these people.

\subsection{Working Hours}

On an average the workers worked 11 months in the last one year, lengthening of the working day and increasing the number of working days are common practices in self-owned enterprises. A large majority of the sample workers worked only a daily sales basis, work like that of electricians and other technical jobs require payment after the work is over, about 13.0 percent of the labourer employed in such jobs.

\subsection{Skill Promotion}

As much as 40.0 percent of all workers felt their work and earning was being affected by technological change, they felt helpless against it due to paucity of their own skill and credit available to them. 


\subsection{Working Conditions and Social Security Benefits}

The analysis focuses on the provision of leave, safety provisions at the workplace, and entitlement for compensation for the injuries. It also focuses on whether the terms and conditions as agreed upon are followed and the employees enjoy the benefits of the provisions of provident fund, Employees' State Insurance and medical reimbursement. The analysis additionally focuses on adherence to the labour laws by the employers relating to different aspects of employment. Nearly 45 percent of the workers reported that they enjoy working for six days with a day off. This practice is comparatively followed more in Delhi than the other sample places (Table 19).

\subsection{Provision of Leave}

There is no provision of leave for a large majority of 89.0 percent of the workers. Leave provisions are not granted to the workers across the sample, not a single worker reported provision of maternity and medical leave in Haryana while in UP, only two workers reported provision of medical leave and one of maternity leave. In Delhi, about 6.0 percent reported provision of medical leave and about 3.0 percent benefited from it (Table 20). Similarly, in Delhi, provision of casual leave, earned leave and sick leave was reported by a comparatively higher percentage of workers than Haryana and UP. On the whole, the provision of leave is just insignificant in all the three states. Each day's absence for any reason accounts for loss of income.

In the informal sector, the benefits enjoyed by the workers are few (Table 21). Casual leave, earned leave and sick leave are not provided by the employers. It is not uncommon to find workers being called to work even 6 7 days a week. Apart from the daily wage earners, for whom each holiday is a loss in income, even monthly and piece rated workers are penalized for taking a day off. There is no provision of paid leave during national holidays and festivals for large majority of workers as nearly 70.0 percent reported no provision of paid leave during holidays. Each holiday meant deduction of the day's earnings.

About the entitlement for compensation in case of injury, accident or sickness, an overwhelming majority of 85.0 percent of workers reported no such provision. This is disturbing as the machinery-related activities can lead to accidents. The government needs to ensure that basic safety provisions are available at workplace for these informal workers too and employers need to be held accountable for all accidents.

Table 19. Number of working days.

\begin{tabular}{ccccccccc}
\hline \multirow{2}{*}{ Working days during a week } & \multicolumn{4}{c}{ Number } & \multicolumn{4}{c}{ Percentages } \\
\cline { 2 - 9 } & Delhi & Haryana & UP & Total & Delhi & Haryana & UP & Total \\
\hline Six days working with a day off & 246 & 99 & 65 & 410 & 49.00 & 45.41 & 33.85 & 44.96 \\
Not a single day off & 256 & 119 & 127 & 502 & 51.00 & 54.59 & 66.15 & 55.04 \\
Total & 502 & 218 & 192 & 912 & 100 & 100 & 100 & 100 \\
\hline
\end{tabular}

Table 20. Provision of leave.

\begin{tabular}{|c|c|c|c|c|c|c|c|c|}
\hline \multirow{2}{*}{ Provision of Leave } & \multicolumn{4}{|c|}{ Number } & \multicolumn{4}{|c|}{ Percentages } \\
\hline & Delhi & Haryana & UP & Total & Delhi & Haryana & UP & Total \\
\hline Casual leave & 41 & 6 & 12 & 59 & 8.17 & 2.75 & 6.25 & 6.47 \\
\hline Earned leave & 48 & 4 & 3 & 55 & 9.56 & 1.83 & 1.56 & 6.03 \\
\hline Sick leave & 22 & 2 & 4 & 28 & 4.38 & 0.92 & 2.08 & 3.07 \\
\hline Medical leave & 28 & 0 & 2 & 30 & 5.58 & 0.00 & 1.04 & 3.29 \\
\hline Maternity leave & 13 & 0 & 1 & 14 & 2.59 & 0.00 & 0.52 & 1.54 \\
\hline No provision of leave & 428 & 208 & 179 & 815 & 85.26 & 95.41 & 93.23 & 89.36 \\
\hline Total & $580^{*}$ & 220 & 201 & 1001 & & & & \\
\hline
\end{tabular}

*Multiple answers. 


\subsection{Provisions of Welfare Schemes}

Information was sought about the availability of welfare schemes to the workers like provident fund (PF) facility, ESI facility, medical benefits, etc. All workers were asked about each scheme and out of 912 workers, an overwhelming majority (90.3 percent) indicated that no such facilities were available to them (Table 22). Only 7.5 percent of the responses indicated that PF facility is available, 5.7 percent indicated that ESI facility is available to them, while a small proportion of about 5.0 percent indicated that medical facilities are provided to them and 3.3 percent indicated that medical bills are reimbursed.

The analysis leads to the conclusion that the situation of these unorganized sector workers is pitiable regarding these very vital facilities of workers' welfare. Though the condition of the surveyed migrants is appalling, and they are perhaps the poorest men around the world, they consider migration to be a step forward for them. Here they have to live in shanty slums, deal with a lot more stress owing to family ties at origin and destination, but they consider their life has improved across all spheres as compared to their village conditions.

\section{Conclusions}

Over the decade, the economy of the NCT and NCR has witnessed spectacular growth, but this has spread total inequality as far as migrant slum dwellers and working in informal activities are concerned. The importance of education was not being fully realized as one-third of the respondents as well as about 50 percent workers were illiterate. Among the literates, higher level of educational attainment was negligible. This has prevented them to acquire marketable skills and denied access to good jobs; it seems very difficult to sustain their survival strategy. In the NCT and NCR regions, the inequality between rich and poor seems to be considerable as the per capita income of this region is the third highest in the country. The gains of this high per capita income did not percolate to the population living in slums.

The comparative characteristics of the sample migrants and of the households at their origin and destinations present a strong empirical support for the importance of economic necessity as a push factor in the decision to migrate. Their socio-economic background reveals that the large majority of the migrants are from the historically disadvantaged classes, due to which they remained landless, illiterate and less educated. In their destinations, they have been staying for the last two and more decades, with some having spent more than 30 to 40 years. For them, the aspiration of better living conditions is still not fulfilled. The fact that workers who mi-

Table 21. Entitlement for compensation in case of injury/accident or sickness.

\begin{tabular}{ccccccccccc}
\hline $\begin{array}{c}\text { Compensation for } \\
\text { injury/accident/sickness }\end{array}$ & Delhi & Haryana & UP & Total & Delhi & Haryana & UP & Total \\
\cline { 2 - 9 } & \multicolumn{5}{c}{ Number } \\
\hline Provision for compensation & 57 & 46 & 34 & 137 & 11.35 & 21.10 & 17.71 & 15.02 \\
No provision of compensation & 445 & 172 & 158 & 775 & 88.65 & 78.90 & 82.29 & 84.98 \\
Total & 502 & 218 & 192 & 912 & 100 & 100 & 100 & 100 \\
\hline
\end{tabular}

Table 22. Employment benefits and facilities.

\begin{tabular}{cccccccccc}
\hline $\begin{array}{c}\text { Availability of benefits } \\
\text { and facilities }\end{array}$ & Delhi & Haryana & UP & Total & Delhi & Haryana & UP & Total \\
\cline { 2 - 8 } PF facility & \multicolumn{7}{c}{ Number } & \multicolumn{7}{c}{ Percentages } \\
ESI facility & 44 & 9 & 15 & 68 & 8.76 & 4.13 & 7.81 & 7.46 \\
Medical benefits & 41 & 8 & 3 & 52 & 8.17 & 3.67 & 1.56 & 5.70 \\
Reimbursement of medical bills & 28 & 1 & 1 & 30 & 5.58 & 0.46 & 0.52 & 3.29 \\
No benefits & 35 & 5 & 4 & 44 & 6.97 & 2.29 & 2.08 & 4.82 \\
Total & 448 & 204 & 176 & 828 & 89.24 & 93.58 & 91.67 & 90.35 \\
\hline
\end{tabular}

Multiple answers. 
grated over 40 years back still live in the same slums, persisting in similar natured occupations is concerning as the ray of hope for their improvement appears bleak. In economic terms, we can say that such persons are long-term poor, that is, their permanent income has been close to their observed income and consumption for a long time. In spite of their unfulfilled expectations, city ward migration is gradually becoming more permanent in a particular city or country.

The workers are mainly employed in temporary jobs; casual work activities form a significant proportion, permanent employees are minimum. Wage and salary workers are concentrated in manufacturing, construction, trade and services. Workers who are illiterate and less educated learned skills on the job while earning. All such experiences about the illiterate and lower level educated workers give a direction about policy implications that how they learn and pick up skills required for their jobs. This underlines the need to develop a training module for illiterate and less educated workers, so that they can be easily absorbed in the urban informal sector. This training should both form skills that have market value and upgrade these skills, and should be considered the core agenda for improving the living standards of poor, informal economy workers. A huge majority of the workers are not deriving statutory benefits like minimum wages, medical assistance, retirement plans or unemployment compensation. Most of the workers are ill informed; they are working in those units whose activities are not regulated under any statutory provision. The denial of the minimum wages and other benefits to workers has deprived them from ensured healthy and educated lives as well as their ability to spend on a range of goods and services.

\section{Suggestions}

From the policy angle the government should provide workers with their basic economic and social security rights; so far state's neglect of the statutory rights in the informal activities has reduced the sustainability among workers. The process of migration is continuing since long, now it is necessary to ensure that government policy and programs recognise the perceptions and priorities of the poor and help to improve their productivity, and diversified employment opportunities. Most migrants in our sample are from rural areas and a large majority of them are landless, for employment in the secondary and tertiary sectors are not yet developed in rural areas. Therefore, there is a notable lack of employment in all sectors of the economy. For reducing pressure in urban areas and one way to solve the migration problem is to take work to the areas of origin, by encouraging new economic activities, such as informal activities in agriculture and the non-agricultural sectors. Similarly, agricultural diversification will enhance worker productivity and eliminate out-migration from land-owning households. Diversification increases secondary and tertiary activities, which provide employment.

However, in spite of several rural development programs, changes in global production networks and increased urbanization have changed the character of rural areas and more and more rural urban migration is taking place. Urban population growth is inevitable; rural migration will be a major component of this growth. But city planners do not desire this influx. Therefore, this perception needs to be changed - migration should be understood to be essential to economic development. The policy makers are ill informed and policy ill suited to supporting migrants. Policy needs to catalyze the integration of slum and squatter settlements into the urban mainstream. In the urban destinations migrants are isolated, live far away from their workplace, and are mostly deprived of mobility and accessibility. Improving their working and living conditions will reduce their economic and social exclusion.

From the policy viewpoint, Indian cities and towns definitely need targeted achievements. Instead of waiting for decades to rehabilitate slum dwellers, it is better to destroy these slums and rebuild modern new accommodation. Investment in urban infrastructure is a key to high economic growth. Regarding the informal activities there is a need to control small unregistered entrepreneurs the government should provide workers their basic economic and social security rights. The state's neglect of statutory rights in the informal sector has increased an exploitation of workers and reduced the employment stability among workers. The standards for work conditions and remuneration must be implemented properly. Similarly the self employed workers are fully insecure and face unique livelihood risks, given their importance to society; there is a need to think about the welfare of such workers. In our sample, the huge majority of the manpower is illiterate or poorly educated, policy must create labour-intensive as well as capital intensive jobs in public and private organized establishments, so that both skilled and unskilled workers can be benefited. There is the need to develop a training module for illiterate and less educated workers in rural and urban areas so that the informal sector can absorb them easily in better productive and remunerative activities. 
Our finding also reveals that the workers lack safety, medical provisions, and social security for self and dependents. Policy should create awareness among officials that resolving these issues would complement to poverty alleviation and, therefore, resources should be made available.

These efforts should be linked with health promotion and disease prevention efforts, so that migrant workers and their dependents can live a healthy and productive life. Government health and social security schemes must be made available to the poor and implementation ensured. Also, participating workers can finance many social security schemes, at least partly. Social security should also extend beyond only the formal sector.

These measures are likely to improve the conditions of migrant informal workers. Policies and programmes which reduce mobility towards big cities are expected to improve the process of development in the backward regions as well as smaller towns.

\section{References}

[1] Bhagat, R.B. (2009) Internal Migration in India: Are the Underclass More Mobile? 26th IUSSP General Population Conference, Marrakech, 27 September-2 October 2009.

[2] Bora, R.S. (1996) Himalayan Migration-A Study of the Hill Region of Uttar Pradesh. Sage, Delhi.

[3] Rao, C.H.H. (2011) India and China: A Comparison of the Role of Sociopolitical Factors in Inclusive Growth. Economic and Political Weekly, 66, 24-28.

[4] de Haan, A. and Rogaly, B. (2002) Migrant Workers and Their Role in Rural Change. Journal of Development Studies, 38, 1-14. http://dx.doi.org/10.1080/00220380412331322481

[5] Mitra, A. (2003) Occupational Choices, Networks, and Transfer: An Exegesis Based on Micro Data from Delhi Slums. Manohar, Delhi.

[6] Reserve Bank of India (2011) Handbook of Statistics on Indian Economy 2010-11.

[7] Census of India (2001) Cities, Towns, and Urban Agglomerations.

[8] Census of India (2011) Provisional Population Total, Rural Urban Distribution Paper 2, Vol. 1 of 2011.

[9] Bhagat, R.B. (2011) Emerging Patterns of Urbanization in India. Economic and Political Weekly, 46, 10-12.

[10] Kundu, A. (2011) Method in Madness: Urban Data from 2011 Census. Economic and Political Weekly, 46, 13-16.

[11] National Sample Survey Organisation, Ministry of Statistics and Programme Implementation, Government of India (2002) Unorganised Manufacturing Sector in India 2000-2001; Employment, Assets, and Borrowings; NSS Round 56, Report No. 479 (56/2.2/3), New Delhi.

[12] National Sample Survey Organisation, Ministry of Statistics and Programme Implementation, Government of India (2006) Employment and Unemployment Situation in India 2004-2005 (Part 1); NSS Round 61, Report No. 515-I and II (61/10/1 \& 2), Delhi.

[13] Department of Health \& Family Welfare, Government of India and International Institute of Population Sciences (2007) National Family Health Survey 3 (2005-06). Volume II, Mumbai.

[14] Varshney, A. (1997) Postmodernism, Civil Engagement, and Ethnic Conflict: A Passage to India. Comparative Politics, 30, 1-20. http://dx.doi.org/10.2307/422190

[15] Bora, R.S. and Tyagi, R.P. (2012) Migrant Workers in the Informal Sector: A Study of Conditions of Work, Health Status and Social Security. Study Submitted to the Indian Council of Social Science Research, Delhi.

[16] Oberai, A.S. and Singh, H.K.M. (1983) Causes and Consequences of Internal Migration-A Study in the Indian Punjab. Oxford University Press, Delhi.

[17] Findley, S.A. (1997) Migration and Family Interactions in Africa. In: Adepoju, A., Ed., Family, Population and Development in Africa, Zed Books, London.

[18] National Commission for Enterprises in the Unorganised Sector (2007) Report Bill.

[19] Banarjee, N. and Nihila, M. (1999) Business Organization in Leather Industries of Calcutta and Chennai. In: Bagchi, A.K., Ed., Economy and Organisation: Indian Industries under the Neoliberal Regime, Sage Publications, New Delhi.

[20] Nihila (2002) Growing Industries, Sick Workers: A Study of Leather Tanning Industry of Dindigul from an Occupational Health Perspective. Review of Development and Change, 7, 134-166.

[21] National Commission for Enterprises in the Unorganised Sector (2007) Report on Conditions of Work and Promotion of Livelihoods in the Unorganised Sector. 